\title{
Stage IVC Major Salivary Gland Cancer AJCC v8
}

National Cancer Institute

\section{Source}

National Cancer Institute. Stage IVC Major Salivary Gland Cancer A/CC v8. NCI Thesaurus.

Code C132790.

Stage IVC includes: Any T, Any N, M1. M1: Distant metastasis. (AJCC 8th ed.) 